\title{
A Novel Role for Somatostatin in the Survival of Mouse Pancreatic Beta Cells
}

\author{
Erin L. Damsteegt ${ }^{\mathrm{a}} \quad$ Zoheb Hassan $^{\mathrm{b}} \quad$ Nirun V. Hewawasam ${ }^{\mathrm{a}}$ \\ Kittiwadee Sarnsamak ${ }^{a}$ Peter M. Jones ${ }^{b} \quad$ Astrid C. Hauge-Evans ${ }^{a}$ \\ aHealth Science Research Group, Department of Life Sciences, University of Roehampton, London, UK, \\ bDepartment of Diabetes, School of Life Course Sciences, King's College London, London, UK
}

\section{Key Words}

Somatostatin • Beta cell survival • Lipotoxicity • Cellular stress • Intra-islet communication • Type 2 diabetes

\begin{abstract}
Background/Aims: Cross-talk between different pancreatic islet cell types regulates islet function and somatostatin (SST) released from pancreatic delta cells inhibits insulin secretion from pancreatic beta cells. In other tissues SST exhibits both protective and pro-apoptotic properties in a tissue-specific manner, but little is known about the impact of the peptide on beta cell survival. Here we investigate the specific role of SST in the regulation of beta cell survival in response to physiologically relevant inducers of cellular stress including palmitate, cytokines and glucose. Methods: Pancreatic MIN6 beta cells and primary mouse islet cells were pre-treated with SST with or without the $\mathrm{G}_{\mathrm{i} / \mathrm{o}}$ signalling inhibitor, pertussis toxin, and exposed to different cellular stress factors. Apoptosis and proliferation were assessed by measurement of caspase 3/7 activity, TUNEL and BrdU incorporation, respectively, and expression of target genes was measured by qPCR. Results: SST partly alleviated upregulation of cellular stress markers (Hspa 1a and Ddit3) and beta cell apoptosis in response to factors such as lipotoxicity (palmitate), pro-inflammatory cytokines (IL1 $\beta$ and TNF $\alpha$ ) and low glucose levels. This effect was mediated via a $G_{i / 0}$ protein-dependent pathway, but did not modify transcriptional upregulation of the specific NFKB-dependent genes, Nos2 and Ccl2, nor was it associated with transcriptional changes in SST receptor expression. Conclusion: Our results suggest an underlying protective effect of SST which modulates the beta cell response to ER stress and apoptosis induced by a range of cellular stressors associated with type 2 diabetes.
\end{abstract}

E. L. Damsteegt and Z. Hassan contributed equally to this work. 


\section{Cellular Physiology Cell Physiol Biochem 2019;52:486-502 \\ \begin{tabular}{ll|l} 
DOl: 10.33594/000000035 & $\begin{array}{l}\text { O } 2019 \text { The Author(s). Published by } \\
\text { Cell Physiol Biochem Press GmbH\&Co. KG }\end{array}$
\end{tabular} \\ Damsteegt et al.: Somatostatin and Pancreatic Beta Cell Survival}

\section{Introduction}

The development of type 2 diabetes is characterized by insulin resistance as well as an increased impairment of pancreatic beta cell function with a corresponding decline in insulin release. This has been ascribed to beta cell loss associated with accelerated levels of apoptosis [1] and is thought to be a consequence of cellular stress caused by a range of factors including gluco- and lipotoxicity and a pro-inflammatory environment characteristic of early type 2 diabetes.

Insulin-secreting beta cells are located within the three-dimensional anatomical structures of the pancreatic islets together with other cell types, the most important of which are glucagon-producing alpha cells and somatostatin-secreting delta cells. It is now clear that the intra-islet environment influences beta cell function and the effect of homotypic crosstalk between beta cells, and of heterotypic interactions between alpha and beta cells, has been studied in some detail by us and others [2-7]. Less attention has been paid to the intra-islet roles of delta cell-derived somatostatin (SST).

We have previously demonstrated that SST released locally from the delta cell exerts a tonic inhibitory effect on hormone secretion from both alpha and beta cells [8]. Recent singlecell transcriptome analysis of mouse and human islet cell types have in addition suggested a pivotal role for the islet delta cell and SST in receiving and mediating external signals from leptin, ghrelin and dopamine signalling pathways [9-11], suggesting a central role for this cell type in the overall integration of central and peripheral inhibitory cues regulating islet secretory function.

In contrast, little information is currently available about the impact of SST on beta cell survival. In addition to release from the islets, SST is also synthesized and secreted by neuroendocrine cells in the central nervous system and in the gastrointestinal and immune systems $[12,13]$. In other tissues SST is reported to inhibit proliferation and promote apoptosis in a number of cancer cells including lung, gastric, colorectal and brain [14, 15]. In contrast, protective and anti-apoptotic properties of SST and analogues have also been shown in a range of contexts, such as in ischemia- and diabetes-induced retinopathies [16-20], following hepatectomy [21] and in models of neurodegenerative diseases such as Alzheimer's Disease [22] and Multiple Sclerosis [23]. The impact of SST on cell survival therefore appears to be tissue specific.

Our recent study of mouse pancreas remodelling during the first three weeks of life showed that the absence of SST had a negative impact on a range of islet mass parameters, leading to decreased proliferation and increased apoptosis [24], thus suggesting a role of the peptide in the regulation of beta cell mass in early life. Although foetal and early life events are crucial for the functional capacity of the beta cell in adult life (e.g. [25]), a significant change in islet size is not seen in adult SST-deficient mice compared to control animals under normal conditions [8]. We therefore suggest that a potential role of SST in beta cell survival is likely to become apparent under conditions of significant organ remodelling such as those seen in early life as reported above, or under conditions of increased physiological stresses, such as during the development of type 2 diabetes. The aim of this study was therefore to investigate the role of SST in beta cell survival with particular focus on the response to physiologically relevant conditions of cellular stress such as lipotoxicity and cytokine-induced inflammation, with subsequent impact on ER stress and cell survival. 


\section{Cellular Physiology Cell Physiol Biochem 2019;52:486-502 \begin{tabular}{ll|l|l|l|l}
\hline DOl: 10.33594/000000035 & ( 2019 The Author(s). Published by \\
\hline
\end{tabular} and BiOchemistry Published online: 15 March 2019 Cell Physiol Biochem Press GmbH\&Co. KG \\ Damsteegt et al.: Somatostatin and Pancreatic Beta Cell Survival}

\section{Materials and Methods}

\section{Tissue culture}

MIN6 beta cells were kindly provided by Professor J-I Miyazaki, University of Tokyo, Japan, and INS1 beta cells by Dr Natasha Hill, Kingston University London, UK. Reagents were from Sigma (Poole, UK) unless otherwise stated. All cell lines were routinely tested for mycoplasma contamination.

MIN6 beta cells (passages 23-40) were maintained in DMEM (10\% [vol/vol] foetal bovine serum, 2 $\mathrm{mmol} / \mathrm{l} \mathrm{L}$-glutamine, $100 \mathrm{U} / \mathrm{ml}$ penicillin $/ 0.1 \mathrm{mg} / \mathrm{ml}$ streptomycin, $25 \mathrm{mmol} / \mathrm{l}$ glucose) and INS1 beta cells (passage 17-25) in RPMI 1640 medium (10\% [vol/vol] foetal bovine serum, 2 mmol/l L-glutamine, $100 \mathrm{U} /$ $\mathrm{ml}$ penicillin/0.1 mg/ml streptomycin, $1 \mathrm{mmol} / \mathrm{l}$ sodium pyruvate, $10 \mathrm{mmol} / \mathrm{l}$ HEPES buffer, $0.05 \mathrm{mmol} / \mathrm{l}$ $\beta$-mercaptoethanol and $11 \mathrm{mmol} / \mathrm{l}$ glucose). Cells were incubated at $37^{\circ} \mathrm{C}$ and $5 \% \mathrm{CO}_{2}$. The medium was changed every 3 days and the cells were passaged and used for experiments when $70-80 \%$ confluent. For some experiments (as indicated) MIN6 beta cells were maintained in supplemented DMEM containing 7.5 $\mathrm{mmol} / \mathrm{l}$ glucose for 4-8 weeks prior to experimental use.

\section{Islet isolation, maintenance and dispersal}

Prior to islet isolations male ICR mice (30g, Charles River Laboratories, Margate, UK) were housed on a 12-h light/dark cycle and had access to food and water ad libitum in accordance with the UK Home Office Regulations. Mouse islets were isolated by collagenase digestion $(1 \mathrm{mg} / \mathrm{ml}$, type XI) and separated from exocrine pancreatic tissue on a histopaque gradient, as described [8]. Islets were incubated overnight at $37^{\circ} \mathrm{C}\left(5 \% \mathrm{CO}_{2}\right)$ in RPMI 1640 medium $(10 \%$ [vol/vol] foetal bovine serum, $2 \mathrm{mmol} / \mathrm{l}$ glutamine, $100 \mathrm{U} / \mathrm{ml}$ penicillin $/ 0.1 \mathrm{mg} / \mathrm{ml}$ streptomycin, $11 \mathrm{mmol} / \mathrm{l}$ glucose) prior to experiments. For islet cell dispersal, islets were washed in PBS and incubated with Accutase (0.2 ml per 2-300 islets) for 8-10 min with intermittent dispersal by gentle pipetting. The reaction was stopped by the addition of PBS and cells were resuspended in RPMI and seeded onto coverslips (50-100, 000 cells/coverslip) in 12-well plates. Incubation studies were commenced after $1 \mathrm{~h}$ as described below.

\section{Incubation studies with cellular stressors}

MIN6 cells were trypsinized and seeded into 96-well plates for measurement of apoptosis, viability or proliferation (15,000 cells/well) and into $6 \mathrm{~cm}$ tissue culture petri dishes $\left(1.5 \times 10^{6}\right.$ cells/dish) for assessment of mRNA expression. Cells were left to adhere overnight after which they were incubated in supplemented DMEM (10\% FBS) with or without SST14 (Bachem AG, Bubendorf, Switzerland) or pertussis toxin (PTX, 100 $\mathrm{ng} / \mathrm{ml}$, Bio-Techne Ltd, Abingdon, UK) as indicated for $48 \mathrm{~h}$. The cells were maintained for an additional 20 or $48 \mathrm{~h}$ in supplemented DMEM (2\% FBS) with or without SST14, PTX and cellular stressors as indicated in the results section. Similar procedures were performed using INS1 cells, isolated islets and dispersed islet cells using supplemented RPMI. Prior to experiments, palmitate was dissolved in 50\% ethanol (vol/vol) and heated at $70^{\circ} \mathrm{C}$ for $10 \mathrm{~min}$, after which it was diluted $1: 10$ with $10 \%(\mathrm{w} / \mathrm{vol})$ filter-sterilised, fatty acid free BSA in DMEM or RPMI as appropriate and incubated for $1 \mathrm{~h}$ at $37^{\circ} \mathrm{C}$. Conjugated palmitate was further diluted 1:10 for a final concentration of $0.5 \mathrm{mmol} / \mathrm{l}$. Control media contained $1 \% \mathrm{BSA}$ and $0.5 \%$ ethanol. Please see Fig. 1A-B and 4A-B for optimisation of palmitate and cytokine concentrations.

\section{Assessment of apoptosis}

Apoptosis was induced in MIN6 and INS1 cells by exposure to the cellular stressors palmitate $(0.5$ $\mathrm{mmol} / \mathrm{l}, 0.95 \% \mathrm{BSA}$ ) with or without 20 or $25 \mathrm{mmol} / \mathrm{l}$ glucose or cytokines (50 U/ml IL1 $\beta$ and $1000 \mathrm{U} / \mathrm{ml}$ TNF $\alpha$, PeproTech EC Ltd, London, UK). It was measured using a Caspase-Glo assay (Promega, Southampton, UK) according to manufacturer's instructions and read on a GloMax Navigator luminometer (Promega, Southampton, UK). In experiments using $5.5 \mathrm{mmol} / \mathrm{l}$ glucose cells were co-treated with SST14 whilst maintained in $5.5 \mathrm{mmol} / \mathrm{l}$ glucose for $48 \mathrm{~h}$ prior to measurement of programmed cell death. In separate experiments whole islets were exposed to different glucose concentrations as indicated for $20 \mathrm{~h}$ prior to assessment of apoptosis. Apoptosis induced in dispersed islet cells was assessed using a TdT (TUNEL) In Situ Apoptosis Detection Kit (DAB) according to manufacturer's instructions (R\&D systems, Bio-Techne Ltd, Abingdon, UK). Results shown are representative data from a minimum of three independent studies with 4-8 replicates per treatment group within experiments. 


\section{Cellular Physiology Cell Physiol Biochem 2019;52:486-502 \\ \begin{tabular}{ll|l} 
and Biochemistry & $\begin{array}{l}\text { DOl: 10.33594/000000035 } \\
\text { Published online: } 15 \text { March 2019 }\end{array}$ & $\begin{array}{l}\text { O 2019 The Author(s). Published by } \\
\text { Cell Physiol Biochem Press GmbH\&Co. KG }\end{array}$ \\
\cline { 2 - 3 } &
\end{tabular} \\ Damsteegt et al.: Somatostatin and Pancreatic Beta Cell Survival}

\section{Cell viability}

MIN6 and INS1 beta cell viability was assessed by measurement of cellular ATP content following treatment with SST14 and/or cellular stressors as described above using a CellTiter-Glo Luminescent Cell Viability Assay (Promega, Southampton, UK).

\section{Proliferation}

DNA synthesis was assessed as a marker of cell proliferation by measuring 5-bromo-2'-deoxyuridine (BrdU) incorporation over $3 \mathrm{~h}$ in MIN6 cells following treatment with SST14. A commercially available kit (Cell Proliferation ELISA, BrdU, Colorimetric, Roche Applied Science, Mannheim, Germany) was used according to the manufacturer's instructions. Results shown are representative data from three independent studies with 8 replicates per treatment group in individual experiments.

\section{$q P C R$}

Islets were harvested or MIN6 cells trypsinised and washed twice in ice-cold PBS. Total RNA was extracted from different treatment groups of islets or MIN6 cells according to the manufacturer's protocol using an RNeasy kit (Qiagen, Sussex, UK) and quantified on a NanoDrop ND-1000 UV/Vis spectrophotometer. Following DNAse treatment (RNase-Free DNase set, Qiagen, Sussex, UK), reverse transcription of RNA to cDNA was performed using Applied Biosystems High-Capacity cDNA Reverse Transcription kit (Fisher Scientific UK Ltd, Loughborough, UK). Quantitative (q)RT-PCR was performed with Light cycler 480 (Roche, UK) and StepOne Plus (Applied Biosystems, UK) real time PCR systems using QuantiFast SYBR Green PCR Kit (Qiagen, Sussex, UK) with 40 cycles of amplification as described previously [26]. Specificity of primer pairs was confirmed by melting curve analyses. Each sample value was normalized to the reference genes

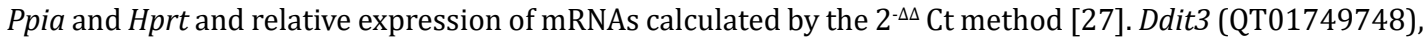
Hsp1a (QT01660064), Ppia (QT00247709), Hprt (QT00166768), Sst (QT00167832), Ccl2 (QT00167832), Nos2 (QT00100275) and Ins2 (QT00114289) primers were obtained from Qiagen (Mt: $60^{\circ} \mathrm{C}$ ) and primers for Sstr1-5 were designed as previously described [8]. Results shown are means \pm SEM of a minimum of three separate experiments.

\section{Data analysis}

Data are expressed as means \pm SEM and analysed statistically using one way ANOVA and Student's $t$ test or Bonferroni's multiple comparisons test, as appropriate. Differences between treatments were considered significant at $\mathrm{P}<0.05$.

\section{Results}

\section{Effect of SST14 on beta cell survival in response to lipotoxicity}

Due to the composite nature of islets consisting of different cell types, the pancreatic beta cell line MIN6 was used as a research model to assess the impact of somatostatin on beta cell survival, thereby excluding any paracrine influences from non-beta cells in the islet, including endogenous SST. Since SST14 is the isoform produced locally in the pancreatic islets, SST14 rather than SST28 was used as an exogenous peptide throughout the study.

It has previously been established that the saturated fatty acid, palmitate, is a diabetogenic factor which induces beta cell death and this was confirmed in MIN6 beta cells (Fig. 1A-D). Pre-incubation with SST14 for $48 \mathrm{~h}$ significantly reduced palmitate-induced apoptosis as shown in Fig. 1C whereas no significant change was observed when cells were maintained under non-stressed, basal conditions. SST receptors signal via both $\mathrm{G}_{\mathrm{i} / \mathrm{o}}$ proteindependent and independent pathways, but the observed reduction in caspase 3/7 activity was mediated via $G_{i / 0}$ signalling, since co-treatment with the $G_{i / 0}$ signalling inhibitor, pertussis toxin, abolished the observed effect (Fig. 1D).

Palmitate induces ER stress and upregulation of the unfolded protein response in beta cells (UPR, [28, 29]). Accordingly, mRNA expression of Hspa1a, which codes for the inducible early stress response protein, heat shock protein 70 (HSP70), and Ddit3, coding for the ER stress-responsive, pro-apoptotic transcription factor, CHOP, were upregulated in MIN6 beta 


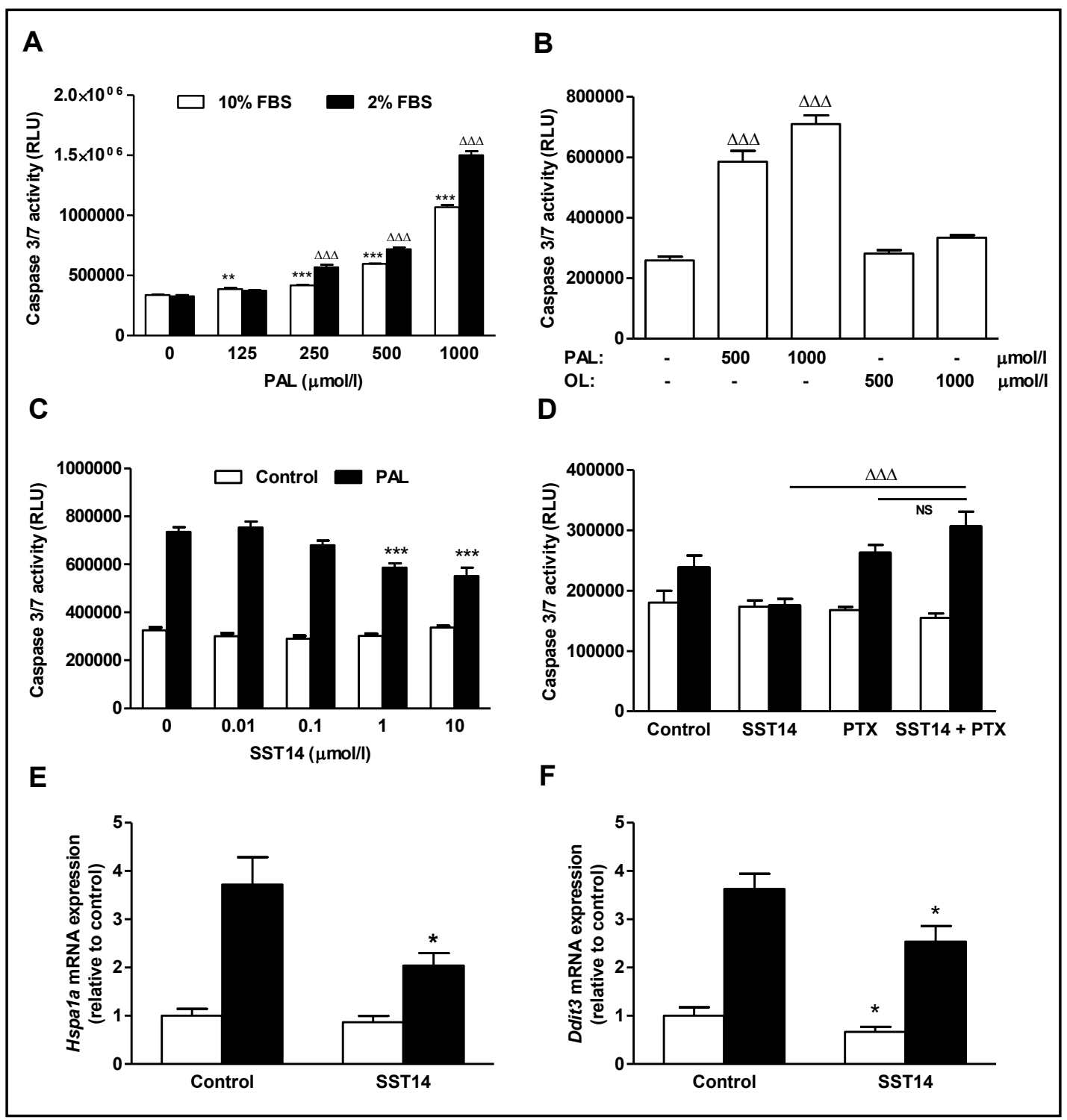

Fig. 1. MIN6 beta cell survival following exposure to palmitate with or without SST14. To optimise the palmitate concentration used for assessment of apoptosis MIN6 beta cells were initially incubated for 20h with increasing concentrations of palmitate (PAL) in DMEM containing 2 or $10 \%$ FBS as indicated (panel A). In a separate set of experiments MIN6 cells were exposed to 0.5 or $1 \mathrm{mmol} / \mathrm{l}$ palmitate or oleate (OL), respectively, with 2\% FBS (panel B). Based on the results, a concentration of $0.5 \mathrm{mmol} / \mathrm{l}$ palmitate was subsequently used to induce beta cell apoptosis. MIN6 beta cells were pre-treated for 48h with SST14 followed by $20 \mathrm{~h}$ incubation with or without palmitate (PAL, black bars) and apoptosis following treatment was assessed by measurement of 3/7 caspase activity (panel C). The observed reduction in apoptosis following SST14 ( $1 \mu \mathrm{mol} / \mathrm{l})$ pre-treatment was reversed by co-incubation with the $\mathrm{G}_{\mathrm{i} / \mathrm{o}}$ inhibitor, pertussis toxin (PTX, $100 \mathrm{ng} / \mathrm{ml}$, panel D). mRNA levels of Hspa1a (panel E) and Ddit3 (panel F) were assessed by qPCR as an indication of cellular and ER stress, respectively, and expression of both were significantly reduced by SST14. Panel A and B: ${ }^{* *} \mathrm{P}<0.01,{ }^{* * *} \mathrm{P}<0.001$ vs $10 \%$ FBS control or ${ }^{\Delta \Delta \Delta} \mathrm{P}<0.001$ vs $2 \%$ FBS control, $\mathrm{n}=8$. Panel $\mathrm{C}-\mathrm{F}:{ }^{*} \mathrm{P}<0.05,{ }^{* * *} \mathrm{P}<0.001$ vs control without SST14, ${ }^{\Delta \Delta} \mathrm{P}<0.001$ SST14 vs SST14 + PTX (one way ANOVA and Bonferroni's multiple comparisons test (A-D) or Student's t test (E and F)). Panel C and D representative of 3-7 experiments. Panel E and F: mean \pm SEM of 4-6 separate experiments. 
Fig. 2. Effect of SST14 pre-treatment on lipotoxicity-induced beta cell apoptosis in primary mouse islet cells. Dispersed mouse islet cells were exposed to 0.5 mmol/l palmitate (PAL) with or without SST14 (100 nmol/l) for 20h following pretreatment with SST14 for 48h. Apoptosis was measured by counting of DABpositive cells following TUNEL staining. Data representative of three separate experiments. ${ }^{* *} \mathrm{P}<0.01$ vs treatment with palmitate only (one way ANOVA and Bonferroni's multiple comparisons test).
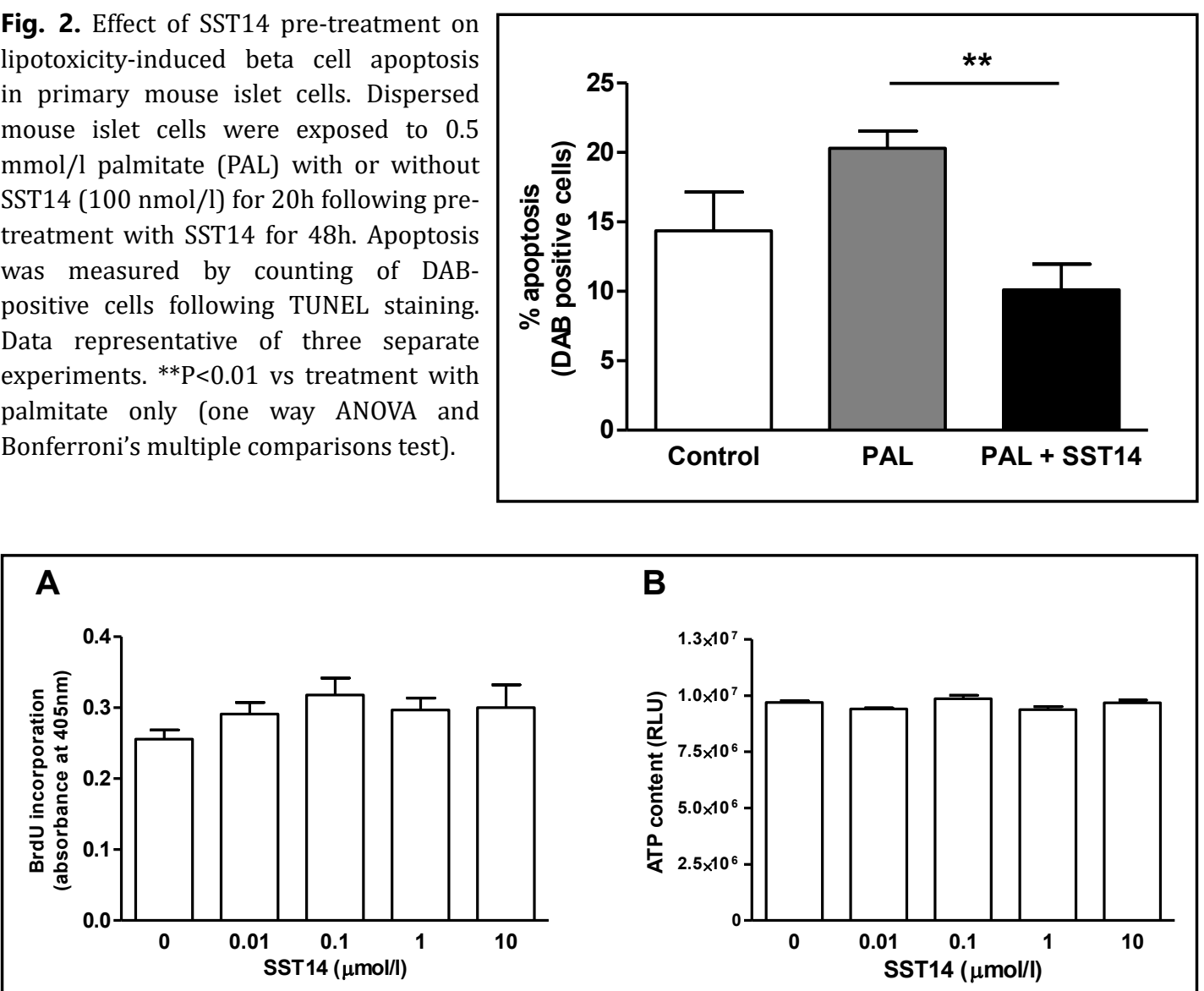

Fig. 3. SST14 does not alter beta cell viability under basal, non-stressed conditions. Beta cell proliferation (panel A) or overall cell viability as measured by ATP content (panel B) was unchanged in MIN6 beta cells maintained in DMEM containing 10\% FBS with increasing concentrations of SST14 for 48h. Data are expressed as means \pm SEM, representative of 3-4 separate experiments.

cells following exposure to palmitate (Fig. 1E-F). Consistent with the effect of SST14 on MIN6 beta cell survival, palmitate-induced mRNA expression of both Hspa1a and Ddit3 were significantly reduced following pre-treatment with SST14 (Fig. 1E-F).

Intact islets contain endogenous SST but islet dispersal leads to a reduction in endogenous Sst mRNA expression by $88 \%(\mathrm{n}=2)$ in populations of dispersed islet cells compared to intact islets, suggesting a loss of SST-secreting delta cells during the dispersal procedure. We therefore assessed the effect of SST14 on apoptosis in dispersed islet cells. Consistent with findings in MIN6 beta cells, palmitate-induced apoptosis was significantly reduced in dispersed islet cells by SST14 after 20h (Fig. 2).

SST has previously been reported to exert anti-proliferative effects particularly in cancer cells, but we did not observe any reduction in rate of proliferation or overall cell viability of MIN6 cells following incubation with SST14 for 48h under normal culture conditions when assessed by measurement of BrdU incorporation or cellular ATP content, respectively (Fig. $3 \mathrm{~A}$ and $\mathrm{B})$.

\section{Effect of SST on beta cell survival in response to other cellular stress factors}

Pro-inflammatory cytokines. To assess whether the observed effect of SST14 on beta cell survival was specific to palmitate-induced ER stress and apoptosis, MIN6 beta cells were exposed to other cellular stress factors of physiological relevance. Fig. 4C shows that cytokine-induced apoptosis ( $50 \mathrm{U} / \mathrm{ml} \mathrm{IL1} \beta$ and $1000 \mathrm{U} / \mathrm{ml} \mathrm{TNF} \alpha$ ) was significantly reduced 
when cells were pre-treated with increasing concentrations of SST14. Cytokines have been reported to induce upregulation of Ddit3 mRNA (e.g. [30, 31]), but in our hands Ddit3 levels were unchanged following $20 \mathrm{~h}$ exposure to a combination of IL1 $\beta$ and TNF $\alpha(\mathrm{P}>0.2)$, although these levels were significantly reduced in the presence of SST14 (1 $\mu \mathrm{mol} / \mathrm{l}$ : $75 \pm 3 \%$ control, $\mathrm{P}<0.01$ ). In contrast, $20 \mathrm{~h}$ exposure of the MIN6 beta cells to IL1 $\beta$ and TNF $\alpha$ led to upregulation of the NFкB-dependent genes Nos2 and $C c 12$, which encode for the enzyme inducible nitric oxide synthase 2 and the chemokine $\mathrm{Ccl} 2$, respectively, from undetectable (Ct values $>35$ ) to clearly measurable levels (Nos2: $\mathrm{Ct}=25.4 \pm 0.9$, Ccl2: 27.1 \pm 0.4$)$. However, no significant change in the upregulation of their mRNA expression was detected when cells were treated with SST14 prior to cytokine exposure (Nos2: $100 \mathrm{nmol} / \mathrm{l}$ SST14: $117 \pm 17 \%$ cytokine control only, $1 \mu \mathrm{mol} / \mathrm{l} \quad$ SST14: $127 \pm 22 \%$; Ccl2: $100 \mathrm{nmol} / \mathrm{l}$ SST14: 112 $\pm 11 \%$ cytokine control only, $1 \mu \mathrm{mol} / \mathrm{l} \mathrm{SST} 14$ : $136 \pm 10 \%, P>0.05$ ), suggesting that the observed effect of SST14 is unlikely to be mediated via direct modulation of $\mathrm{NF} \kappa \mathrm{B}$ expression and/or activation. Consistent with previous reports [32], 20h exposure to palmitate did not induce upregulation of Nos2 and Ccl2 mRNA expression in MIN6 cells, and mRNA for both genes was indeed undetectable under both control and palmitate-induced conditions.

Hyperglycaemia and glucolipotoxicity. Under standard conditions, the MIN6 cell line does not lend itself to studies on the impact of hyperglycaemia on beta cell survival given the recommended culture conditions of $25 \mathrm{mmol} / \mathrm{l}$ glucose [33], so we investigated the effect of high glucose in MIN6 beta cells maintained in media containing $7.5 \mathrm{mmol} / \mathrm{l}$ glucose for 4-8 weeks prior to experiments and in the rat beta cell line INS1, which is maintained at $11 \mathrm{mmol} / \mathrm{l}$ glucose. Under these conditions MIN6 cells maintained their proliferative capacity

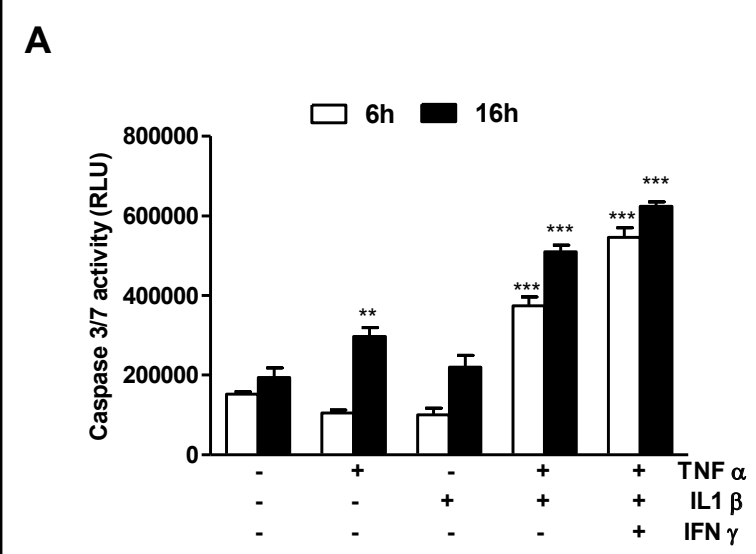

B

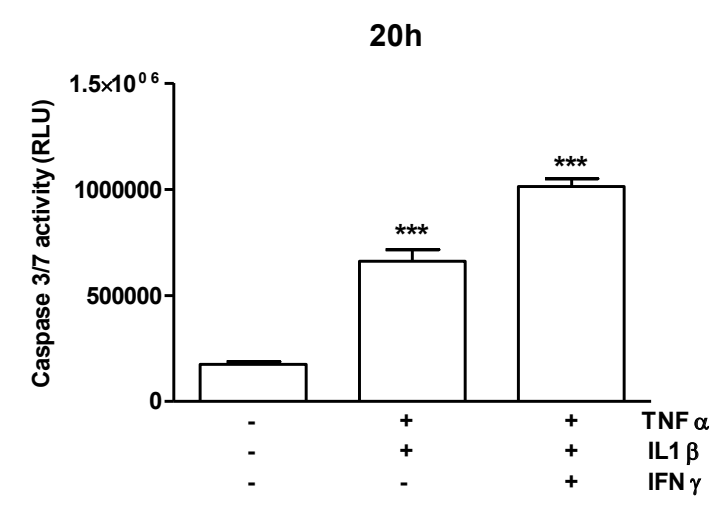

C

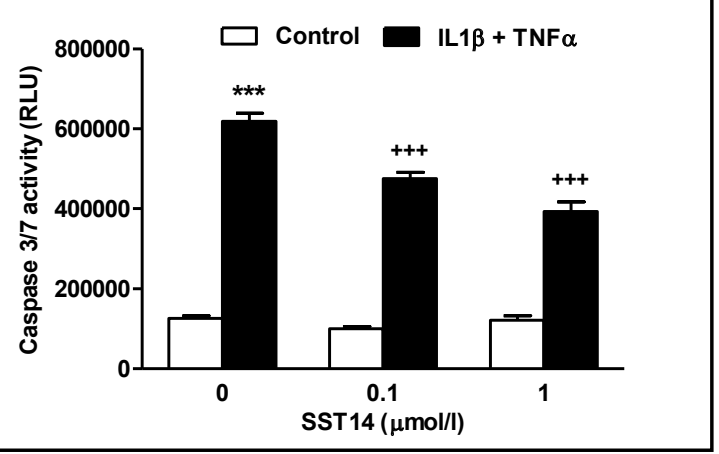

Fig. 4. Role of SST14 in beta cell survival following exposure to pro-inflammatory cytokines. To identify an effective exposure time and cytokine combination for assessment of apoptosis, MIN6 cells were initially exposed to TNF $\alpha$ and IL1 $\beta$ alone or in combination for 6,16 or $20 \mathrm{~h}$ as well as to TNF $\alpha$, IL1 $\beta$ and IFN $\gamma$ combined $(1000$ $\mathrm{U} / \mathrm{ml}, 50 \mathrm{U} / \mathrm{ml}$ and $1000 \mathrm{U} / \mathrm{ml}$, respectively, panel A and $B, n=4$ ). Based on the results, apoptosis was subsequently assessed in MIN6 beta cells pre-treated with SST14 for $48 \mathrm{~h}$ prior to $20 \mathrm{~h}$ incubation with $50 \mathrm{U} / \mathrm{ml} \mathrm{IL} 1 \beta$ and 1000 $\mathrm{U} / \mathrm{ml} \mathrm{TNF} \alpha$ panel $\mathrm{C}$, data representative of three separate experiments). ${ }^{* * *}<<0.001$ vs control without cytokines as appropriate, ${ }^{+++} \mathrm{P}<0.001$ SST14 vs control (one way ANOVA and Bonferroni's multiple comparisons test). 


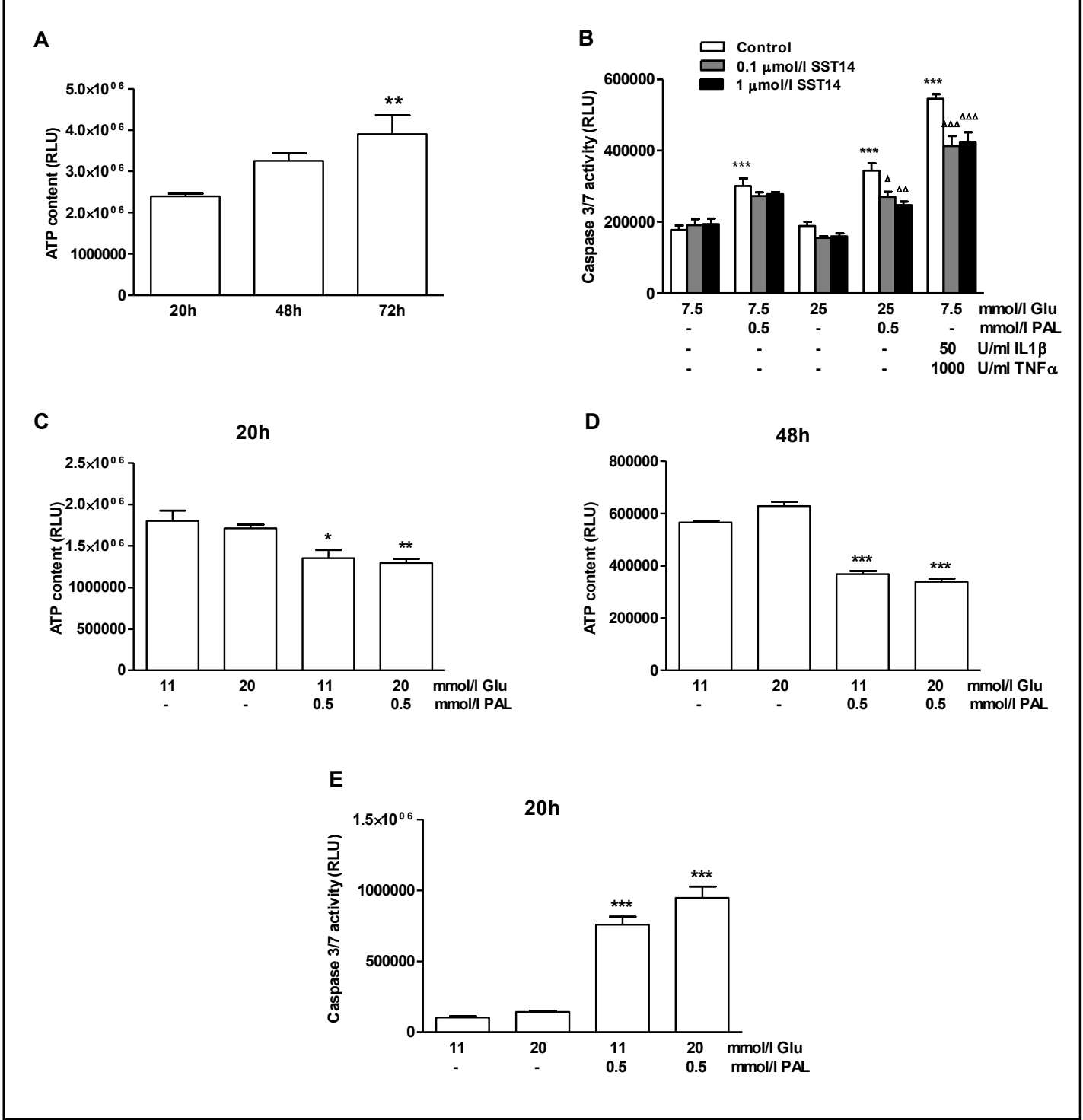

Fig. 5. Effect of SST14 on MIN6 and INS1 beta cell viability and apoptosis following exposure to gluco- and/ or lipotoxicity. To investigate the role of SST14 in hyperglycaemia- and glucolipotoxicity-induced apoptosis, MIN6 cells were maintained in prolonged culture at $7.5 \mathrm{mmol} / \mathrm{l}$ glucose (Glu). Initially the rate of cell growth decreased, however, after approximately three weeks cell expansion resumed, as shown by an increase in ATP content and thus number of metabolically active cells with time (A). The cells were subsequently pretreated for $48 \mathrm{~h}$ with SST14 followed by $20 \mathrm{~h}$ exposure to $25 \mathrm{mmol} / \mathrm{l}$ glucose, $0.5 \mathrm{mmol} / \mathrm{l}$ palmitate (PAL) or a combination of both, or to IL1 $\beta$ and TNF $\alpha$ all with or without SST14 (B). INS1 cells were exposed to $20 \mathrm{mmol} / \mathrm{l}$ glucose, $0.5 \mathrm{mmol} / \mathrm{l}$ palmitate (PAL) or a combination of both for 20 (C, E) or 48h (D) and cell viability (C, D) or apoptosis (E) was assessed by measurement of ATP content and caspase 3/7 activity, respectively. ${ }^{*} \mathrm{P}<0.05,{ }^{* *} \mathrm{P}<0.01,{ }^{* * *} \mathrm{P}<0.001$ vs control (one way ANOVA, followed by Bonferroni's multiples comparison test). Data shown in each panel are representative of three separate experiments.

(Fig. 5A) and the cells did not exhibit significantly altered gene expression of Ddit3, Hspa1a or Ins2, Sstr1, Sstr2, Sstr3 and Sstr5 compared to cells maintained in $25 \mathrm{mmol} / \mathrm{l}$ (Table 1). In both experimental settings we found that 20 or $48 \mathrm{~h}$ exposure to high concentrations of glucose did not lead to increased caspase 3/7 activity (MIN6: 20h exposure to $25 \mathrm{mmol} / \mathrm{l}$ glucose: $107 \pm 7 \%$ of caspase $3 / 7$ activity at $7.5 \mathrm{mmol} / \mathrm{l}$ glucose; $48 \mathrm{~h}: 104 \pm 16 \%$; INS1: $20 \mathrm{~h}$ 


\section{Cellular Physiology Cell Physiol Biochem 2019;52:486-502 \\ \begin{tabular}{ll|l} 
and Biochemistry Published online: 15 March 2019 & $\begin{array}{l}\text { C } 2019 \text { The Author(s). Published by } \\
\text { Cell Physiol Biochem Press GmbH\&Co. KG }\end{array}$
\end{tabular} \\ Damsteegt et al.: Somatostatin and Pancreatic Beta Cell Survival}

exposure to $20 \mathrm{mmol} / \mathrm{l}$ glucose: $118 \pm 14 \%$ of activity at $11 \mathrm{mmol} / \mathrm{l}$ glucose, $\mathrm{P}>0.1$, Fig. 5B, E) nor did it cause a decrease in cell viability of INS1 cells (Fig. 5CD). These findings are consistent with reports suggesting that a combination of lipo- and glucotoxicity is a more potent beta cell stressor in beta cells and islets than glucose alone [34], and MIN6 cells were therefore exposed to a combination of 25 $\mathrm{mmol} / \mathrm{l}$ glucose and $0.5 \mathrm{mmol} / \mathrm{l}$ palmitate for $20 \mathrm{~h}$. Under these conditions $48 \mathrm{~h}$ pre-treatment with SST14 partly reduced the detrimental effect of palmitate and glucose on cell survival in MIN6 cells (Fig. 5B) although the combination of glucose and palmitate did not further increase caspase 3/7 activity compared to $0.5 \mathrm{mmol} / \mathrm{l}$ palmitate alone $(\mathrm{P}>0.1)$. As was the case with cells maintained at $25 \mathrm{mmol} / \mathrm{l}$ glucose, cytokine-induced apoptosis was reduced following pre-treatment with SST14 (Fig. 5B).

Low glucose and serum. We have previously reported that increasing glucose concentrations (5-25 mmol/l) can exhibit a protective, rather than a detrimental, effect on beta cell survival and reduce caspase activity levels induced by prolonged exposure to low glucose in MIN6 beta cells (48h, $2.5 \mathrm{mmol} / \mathrm{l}$, [35]). Efanova et al. [36] similarly found that $40 \mathrm{~h}$ incubation with $5 \mathrm{mmol} / \mathrm{l}$ glucose or below led to increased cell death in rodent islets compared to $11 \mathrm{mmol} / \mathrm{l}$ glucose, a concentration which is generally accepted as being optimal for maintaining rodent islets in culture [36, 37]. In the present study we also observed an increase in caspase $3 / 7$ activity of islets exposed to low glucose concentrations for $20 \mathrm{~h}(5 \mathrm{~mol} / \mathrm{l}$ glucose: $259 \pm 34 \%$ caspase $3 / 7$ activity at $11 \mathrm{mmol} / \mathrm{l}$ glucose, $0 \mathrm{mmol} / \mathrm{l}$ glucose: $226 \pm 34 \%, \mathrm{P}<0.05$ ). Consistent with these findings, $48 \mathrm{~h}$ exposure of MIN6 beta cells to $5.5 \mathrm{mmol} / \mathrm{l}$ glucose significantly increased beta cell apoptosis compared to controls and this effect was abolished by $48 \mathrm{~h}$ co-incubation with SST14 (Fig. 6A).

The PERK-ATF4 signalling branch of the unfolded protein response (UPR) is reportedly upregulated by low glucose concentrations, leading to increased expression of pro-apoptotic ATF4 target genes, including Ddit3 [37]. Ddit3 mRNA expression was not, however, further increased by exposure to $5.5 \mathrm{mmol} / \mathrm{l}$ glucose compared to controls (Fig. 6B). This may reflect the fact that $48 \mathrm{~h}$ exposure to control media containing 2\% FBS compared to $10 \%$ FBS led to a significant two-fold increase in Ddit3 mRNA levels on its own, suggesting that prolonged reduction in serum levels itself constitutes a stress factor (Fig. 6B). A similar, although not statistically significant, trend of increased expression was seen in MIN6 cells after 20h culture at $2 \%$ FBS $(150 \pm 29 \%$ of caspase activity at 10\% FBS), although these findings did not manifest themselves in increased levels of caspase activity. Thus exposure to decreasing concentrations of serum for 20 or $48 \mathrm{~h}$ did not induce apoptosis at concentrations used routinely in this study (Fig. 6C-D). Nevertheless, under all these conditions pre-treatment with $1 \mu \mathrm{mol} / \mathrm{l}$ SST14 significantly reduced Ddit3 mRNA expression (Fig. 1F and 6B).

\section{SST receptor expression under conditions of cellular stress}

MIN6 cells express $S s t r 1,2,3$ and 5 mRNA with $S$ str 3 in particular being highly expressed, as has also recently been reported for beta cells in single islet cell transcriptome studies $([9,10]$, Fig. 7A). Previous reports suggest that G-protein-coupled receptor (GPCR) mRNA expression including that of SSTRs can be altered in response to various forms of cellular stress factors such as inflammation and hyperglycaemia $[23,38]$. Sstr mRNA expression was therefore determined following exposure to palmitate and cytokines at concentrations and durations investigated above.

Table 1. Gene expression in MIN6 cells maintained for 4-8 expressed relative to the house keeping gene Ppia. Results are shown as means \pm SEM of 3-4 separate cell preparations, where

\begin{tabular}{lccc}
\hline Gene & $25 \mathrm{mmol} / \mathrm{l}$ glucose & $7.5 \mathrm{mmol} / \mathrm{l}$ glucose & P value \\
\hline Ddit3 & $0.10 \pm 0.008$ & $0.09 \pm 0.003$ & 0.29 \\
Hspa1a & $3.85 \pm 0.80 \times 10^{-4}$ & $2.12 \pm 0.18 \times 10^{-4}$ & 0.06 \\
Ins2 & $64.62 \pm 4.42$ & $63.07 \pm 4.51$ & 0.82 \\
Sstr1 & $1.60 \pm 0.27 \times 10^{-4}$ & $1.48 \pm 0.34 \times 10^{-4}$ & 0.81 \\
Sstr2 & $1.15 \pm 0.38 \times 10^{-4}$ & $1.29 \pm 0.19 \times 10^{-4}$ & 0.73 \\
Sstr3 & $10.87 \pm 3.10 \times 10^{-3}$ & $7.98 \pm 1.47 \times 10^{-3}$ & 0.40 \\
Sstr5 & $4.20 \pm 2.17 \times 10^{-3}$ & $2.29 \pm 0.28 \times 10^{-3}$ & 0.35 \\
\hline
\end{tabular}

. 


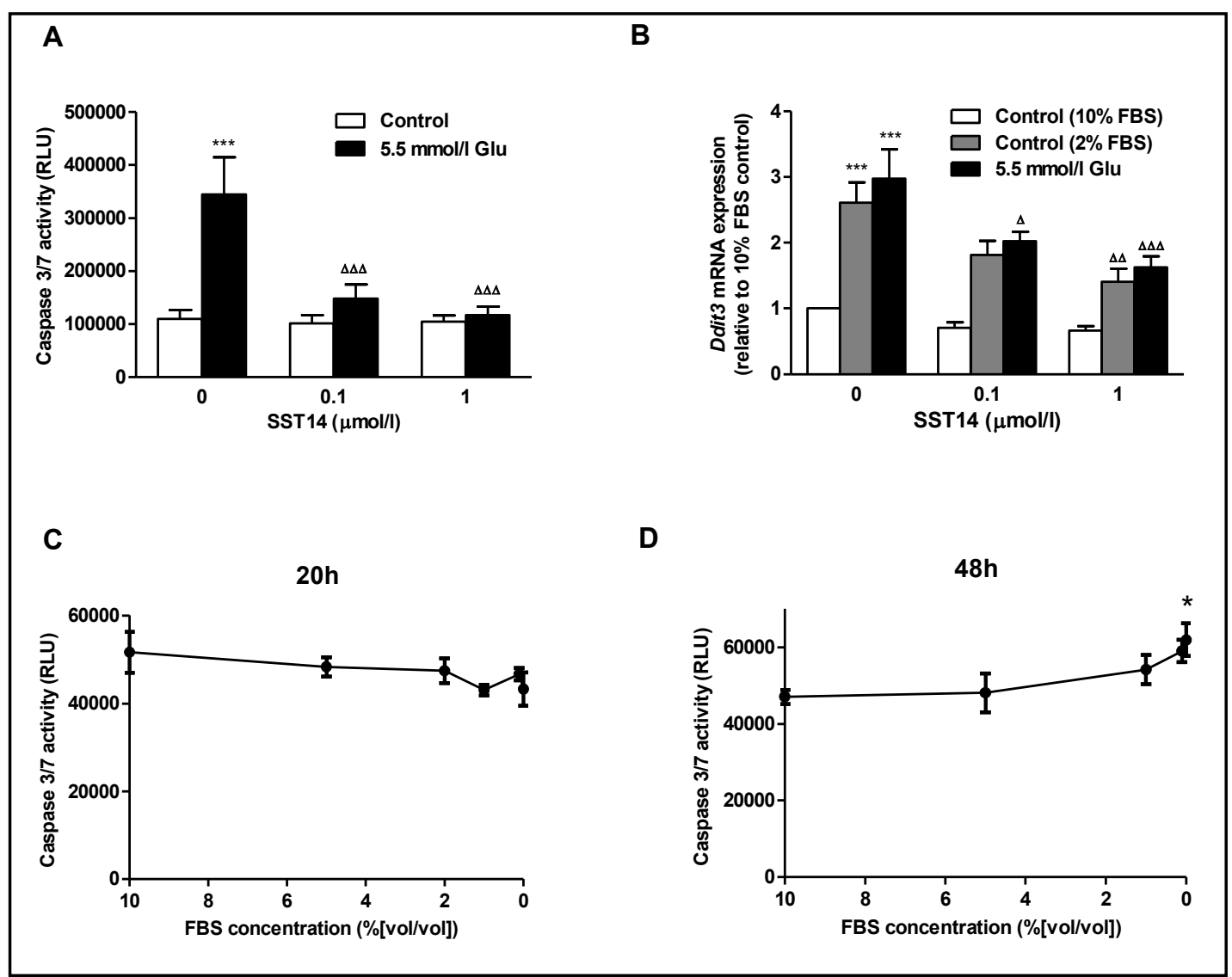

Fig. 6. Beta cell survival following glucose or serum deprivation. Incubation of MIN6 beta cells with 5.5 $\mathrm{mmol} / \mathrm{l}$ glucose (Glu) for $48 \mathrm{~h}$ increased caspase $3 / 7$ activity, which was abolished by co-incubation with SST14 (panel A). Ddit3 mRNA expression was not upregulated by $48 \mathrm{~h}$ incubation with $5.5 \mathrm{mmol} / \mathrm{l}$ glucose compared to $2 \%$ FBS control treatment, however, Ddit3 levels were increased by $48 \mathrm{~h}$ incubation in $2 \%$ FBS with or without $5.5 \mathrm{mmol} / \mathrm{l}$ glucose compared to $10 \%$ FBS controls (panel B). Pre-treatment with SST14 (48h) reduced mRNA expression under both conditions (panel B). To investigate the effect of serum deprivation on MIN6 beta cell survival, cells were exposed to decreasing concentrations of fetal bovine serum (FBS) for 20 or $48 \mathrm{~h}$ and apoptosis assessed (panel $\mathrm{C}$ and $\mathrm{D}, \mathrm{n}=8$ ). Panel A-B: ${ }^{* * *} \mathrm{P}<0.001$ treatment vs control, ${ }^{\Delta} \mathrm{P}<0.05,{ }^{\Delta \Delta} \mathrm{P}<0.01,{ }^{\Delta \Delta} \mathrm{P}<0.001$ SST14 vs control. Panel C-D: ${ }^{*} \mathrm{P}<0.05$ vs control media containing $10 \%$ FBS, (one way ANOVA and Bonferroni's multiple comparisons test). Panel A: data representative of three separate experiments, panel B: mean \pm SEM of three separate experiments.

Culture for 20h with palmitate or cytokines did not alter Sstr mRNA levels compared to controls in a consistent manner (Fig. 7B-E), nor did 2\% FBS on its own have any effect (data not shown). However, Sstr3 expression was reduced in the presence of cytokines $(\mathrm{P}<0.05$, Fig. 7D) and Sstr 1 and 2, but not $S s t r 3$ and $5 \mathrm{mRNA}$ expression was significantly upregulated by prolonged (48h) exposure to $2 \%$ FBS (Fig. 8A-D).

Overall, pre-incubation with SST14 prior to conditions of stress did not significantly change receptor expression although under conditions of prolonged exposure to low serum levels Sstr1 and 5 mRNAs were down-regulated (Fig. 8A and D). These results suggest that in our experimental setting, Sstr transcription was not universally up- or downregulated in response to stress factors such as palmitate or cytokines, although serum deprivation impacted on mRNA levels in a divergent manner which was dependent on receptor subtype. The observed effect of SST14 on beta cell survival is therefore unlikely to be a result of transcriptional changes at receptor level. 
A

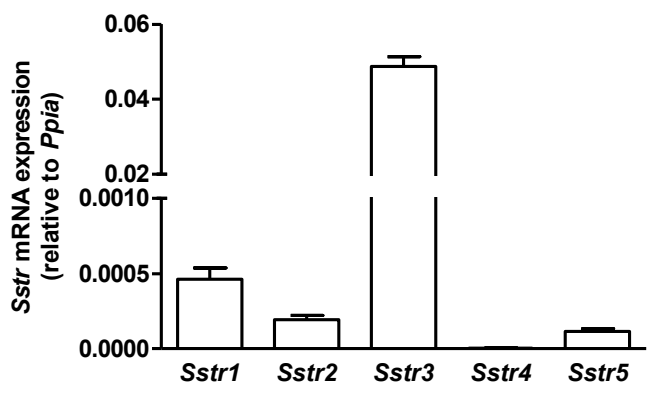

B

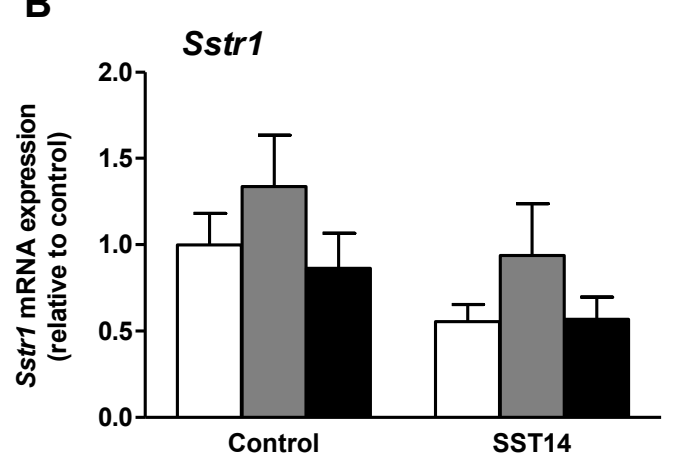

D

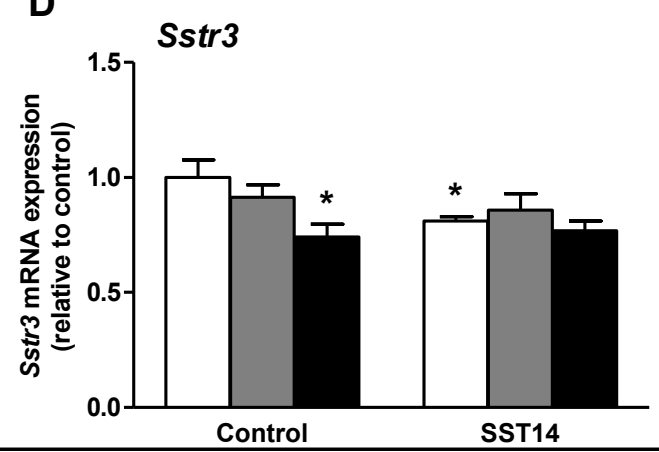

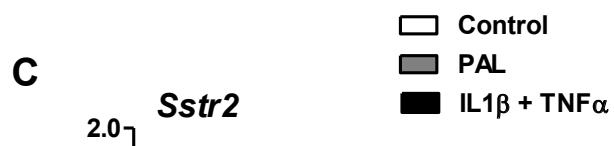

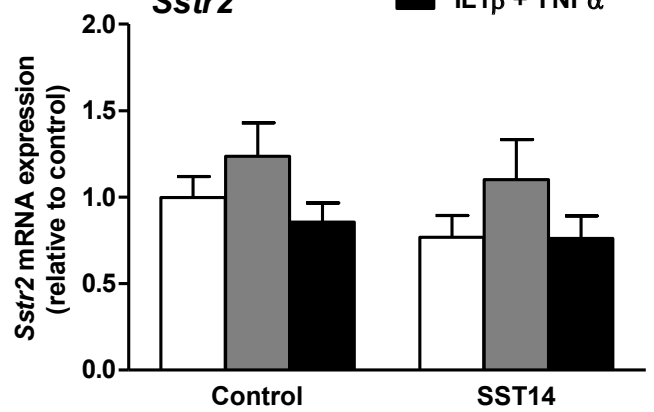

E

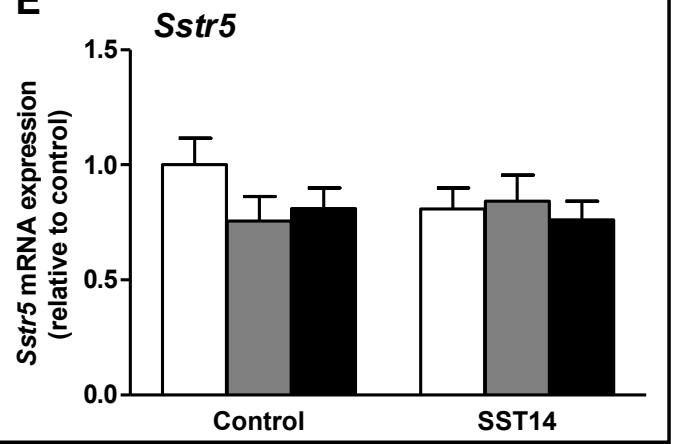

Fig. 7. Effect of SST14 on SSTR receptor expression under conditions of lipid and cytokine toxicity. Sstr mRNA expression was assessed in MIN6 beta cells by qPCR under normal culture conditions (panel A) or following pre-treatment with $1 \mu \mathrm{mol} / \mathrm{l} \mathrm{SST} 14$ for $48 \mathrm{~h}$ followed by $20 \mathrm{~h}$ exposure to $0.5 \mathrm{mmol} / \mathrm{l}$ palmitate (PAL) or cytokines $(50 \mathrm{U} / \mathrm{ml} \mathrm{IL1} \beta$ and $1000 \mathrm{U} / \mathrm{ml} \mathrm{TNF} \alpha$ ), with or without SST14. Panels B-E show results for Sstr 1, 2, 3, and 5, respectively. ${ }^{*} \mathrm{P}<0.05$, vs control (one way ANOVA and Bonferroni's multiple comparisons test). Data presented as means \pm SEM of 6-8 separate experiments.

\section{Discussion}

The importance of intra-islet SST in the regulation of pancreatic hormone secretion is well-established, but at present there is little information regarding a potential role of the peptide in the regulation of beta cell survival. Here we report the novel finding that the level of beta cell apoptosis following exposure to physiologically relevant cellular stressors is reduced by SST14. Our results indicate that the action of SST14 is likely to involve an underlying protective mechanism rather than being linked to specific conditions of cellular stress and subsequent cell death. 
A

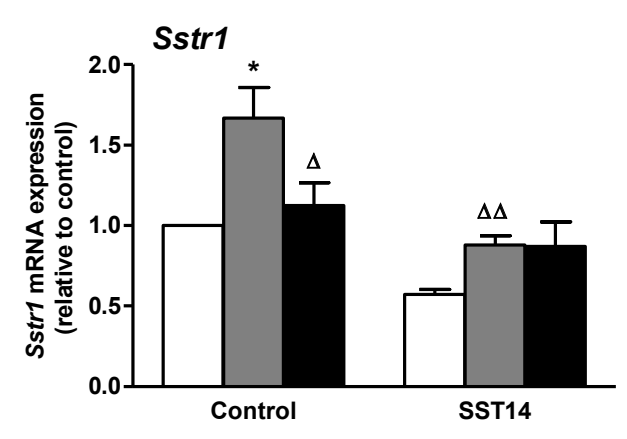

C

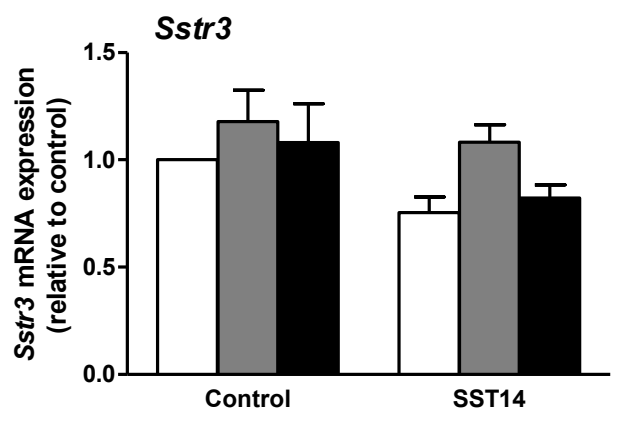

B

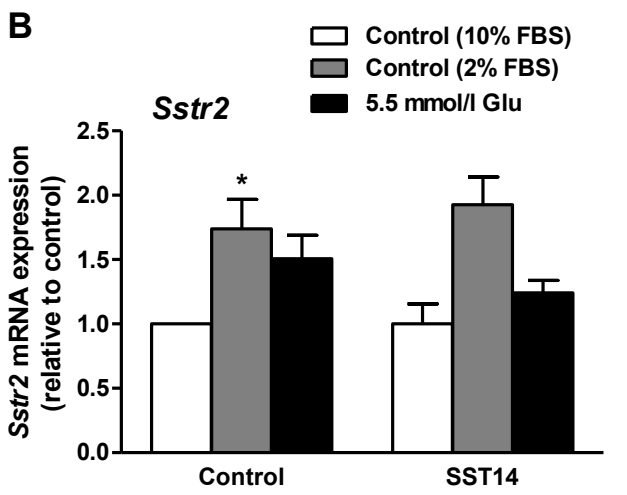

D

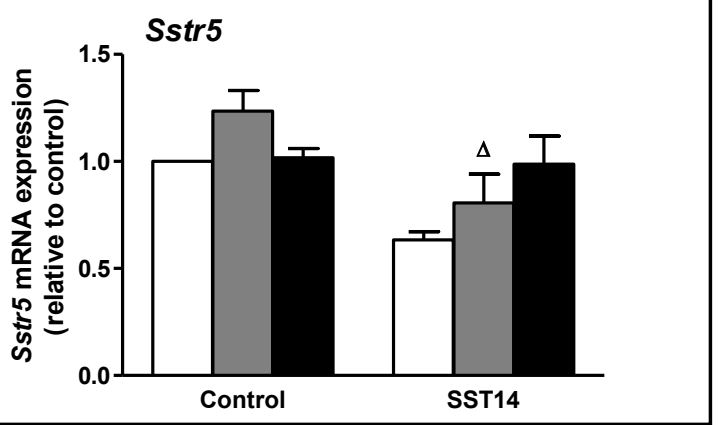

Fig. 8. Effect of SST14 on SSTR receptor expression under conditions of glucose and serum deficiency. Sstr mRNA expression was assessed in MIN6 beta cells by qPCR following pre-treatment with $1 \mu$ mol/l SST14 for $48 \mathrm{~h}$ (10\% FBS) followed by $48 \mathrm{~h}$ exposure to $5.5 \mathrm{mmol} / \mathrm{l}$ glucose (Glu, 2\% FBS) or $2 \%$ FBS alone with our without SST14. Panels A-D show results for Sstr 1, 2, 3, and 5, respectively. ${ }^{*} \mathrm{P}<0.05$ vs $10 \%$ FBS control, ${ }^{\triangle} \mathrm{P}<0.05$ vs $2 \%$ FBS (one way ANOVA and Bonferroni's multiple comparisons test). Data expressed as means \pm SEM of four separate experiments.

We initially chose to investigate the impact of SST treatment on cellular responses to lipotoxicity since this is a key contributor to beta cell dysfunction and damage in the development of type 2 diabetes. The saturated free fatty acid, palmitate, exerts a number of detrimental effects which under chronic conditions leads to beta cell dysfunction and apoptosis $[32,39]$. This was confirmed in our study by the induction of cellular stress as reflected in increased mRNA expression of Hspa1a coding for Hsp70, by upregulation of the ER stress-responsive, pro-apoptotic transcription factor, Ddit3, and ultimately by upregulation of caspase 3/7 activity indicating onset of apoptosis. Assessment of these parameters confirmed a protective role of SST14 in response to lipotoxicity in the pancreatic beta cell line MIN6.

The study of SST14 in primary islets is complicated by the presence within islets of different cell types including SST14-secreting delta cells that are likely to be associated with high local concentrations of endogenous SST14. In our hands dispersal of islets into single cell suspensions led to substantial reduction in SST expression and we were thus able to confirm our findings on the protective effects of SST14 from MIN6 cells in primary islet cells.

Both type 1 and type 2 diabetes are associated with an inflammatory insult of the beta cells and lipotoxcity itself also leads to the generation of inflammatory factors from adipose tissue [40]. We therefore assessed whether the observed protective effect of SST14 extended to this type of cellular stress. The detrimental impact of circulating fatty acids or cytokines on beta cells is mediated via a range of mechanisms, overlapping as well as diverging [30, 32, $39]$. Thus, both these stress conditions can for example induce ER stress $[28,41]$ although 


\section{Cellular Physiology Cell Physiol Biochem 2019;52:486-502 \\ \begin{tabular}{ll|l} 
and Biochemistry $\begin{array}{l}\text { DOl: 10.33594/000000035 } \\
\text { Published online: 15 March 2019 }\end{array}$ & $\begin{array}{l}\text { O } 2019 \text { The Author(s). Published by } \\
\text { Cell Physiol Biochem Press GmbH\&Co. KG }\end{array}$ \\
\cline { 2 - 3 } & Damb
\end{tabular}}

potentially by different means. Our study confirmed a protective effect of SST14 on beta cell survival following cytokine as well as palmitate exposure although we did not observe an upregulation of the ER stress responsive transcription factor Ddit3 in response to cytokines. This does not, however, exclude potential involvement of other arms of the UPR, ER stress and apoptotic pathways. NFkB is another key transcription factor which upon activation initiates cytokine-induced apoptosis via transcriptional regulation of downstream target genes such as Nos2 and the chemokine Ccl2. Excessive NO production by inducible nitric oxide synthase 2 leads to ER stress [42] and expression of both Ccl2 and Nos2 mRNAs were increased in MIN6 cells following cytokine treatment. SST14 did not, however, modify the upregulation of these target genes, thus questioning an impact of SST14 on NFkB. The specific underlying pathways being modulated by SST14 therefore remain to be further investigated.

Hyperglycaemia had little detrimental effect on caspase 3/7 activity in both INS1 and MIN6 cells and our results suggest that lipotoxicity rather than glucotoxicity is the main stress factor in our experimental models, although it is possible that high glucose concentrations negatively affect beta cell survival via caspase 3/7 independent pathways. Regardless, the observed protective effect of SST14 on beta cell apoptosis was maintained in MIN6 beta cells under these conditions as was also the case in response to the negative, although less severe effects of prolonged exposure to low glucose levels which could be important in times of fasting. Overall our results suggest that prolonged exposure to SST14 partly protects beta cells against a range of physiologically relevant cellular stressors. We note in particular that the use of different surrogate markers for beta cell stress and apoptosis resulted in varied outcomes depending on the type of stressor involved, suggesting that these markers are not necessarily linked in a causal manner. Nevertheless, the overall effect of SST14 was consistently that of beta cell protection.

We have previously found that hyperglycaemia leads to changes in the expression in islets of another GPCR, the muscarinic M3 receptor, with subsequent consequences for islet function [38]. In a recent single cell transcriptome study SSTR mRNA expression was increased in islet cells from human type 2 diabetes islet samples compared to healthy controls [11] and another study reported of SSTR2 and 4 upregulation in human brain endothelial cells in response to cytokines and lipopolysaccharides (LPS, [23]). Although we observed some minor changes in individual receptor expression in response to cytokines and $48 \mathrm{~h}$ culture in low serum, these changes were not uniform in response to the different types of cellular stresses both with regards to receptor subtype and to transcriptional up - or downregulation. Importantly, the observed minor changes were not consistently counteracted by SST14 treatment (which in other experiments alleviated beta cell apoptosis in response to a range of cellular stress factors), suggesting that the impact of SST14 on beta cell apoptosis is unlikely to be dependent on transcriptional changes of the SSTRs.

Our data indicate that SST14 mediates its effect on beta survival via pertussis toxin sensitive $G_{i / o}$ protein coupled signalling. It is beyond the scope of this study to identify specific components of the intracellular transduction pathway(s) involved, particularly given the complexity of receptor subtypes and formation of potential homo- or hetero-oligomeric receptor complexes with differential links to the intracellular signalling machinery. In the beta cell SST inhibits insulin secretion via inhibition of adenylate cyclase, $\mathrm{K}_{\mathrm{ATP}}$ channels, $\mathrm{Ca}^{2+}$ influx as well as via action at distal sites of exocytosis [43, 44]. SST also inhibits the release of cytokines from a range of immune and endothelial cells [45] and islets similarly have the capacity to release a vast secretome of cytokines. It is therefore conceivable that SST mediates its effect on survival via a similar inhibitory action on releasable factors (other than NO and Ccl2) involved in the apoptotic response of the beta cell.

SST14 had little effect on cell viability, proliferation and survival under non-stressed conditions. This is consistent with previous findings in 8-12 week old Sst-deficient mice, where no significant change in islet size was observed compared to control animals under normal conditions [8]. In contrast, lack of SST led to increased apoptosis during pancreas remodelling in early life [24] and our current results confirm the suggestion that the protective effect of SST is particularly relevant under conditions of beta cell stress such as 


\section{Cellular Physiology Cell Physiol Biochem 2019;52:486-502 \\ \begin{tabular}{ll|l} 
and Biochemistry & $\begin{array}{l}\text { DOl: 10.33594/000000035 } \\
\text { Published online: } 15 \text { March 2019 }\end{array}$ & $\begin{array}{l}\text { O } 2019 \text { The Author(s). Published by } \\
\text { Cell Physiol Biochem Press GmbH\&Co. KG }\end{array}$ \\
\cline { 2 - 3 } & Dams
\end{tabular} \\ Damsteegt et al.: Somatostatin and Pancreatic Beta Cell Survival}

for example during the development of type 2 diabetes. Consistent with these findings a recent study by Luque et al. [46] showed that Sst-deficient mice fed a low fat diet exhibited a normal metabolic phenotype, whereas a high fat diet for 12-14 weeks led to gender-specific impairment of glucose metabolism. Thus, male Sst-deficient mice exhibited increased fasting glucose levels and impaired glucose clearance whereas there were no observed changes in insulin tolerance compared to wild type mice fed a high fat diet.

Increases in the number of delta cells have been observed in type 1 diabetes [47, 48] whereas there are diverging reports regarding changes in delta cell mass of both patients and animal models of type 2 diabetes [48-51]. Functionally, glucose-induced SST secretion appears to be impaired in both types of the condition (reviewed in [52]) and it is therefore conceivable that imbalances in SST release not only impact insulin secretion in the development of type 2 diabetes, but may also directly affect the overall survival of the beta cell during this period via separate mechanisms. This hypothesis is supported by our present findings and suggests that intra-islet communication between pancreatic beta cells and non-beta cells such as the delta cell is critical for optimal maintenance of a functional beta cell mass, which in turn has implications for the onset of type 2 diabetes.

\section{Acknowledgements}

The authors would like to thank Dr Sue Reeves and Dr Michael Patterson, University of Roehampton, UK, for valued contribution to experimental design and project development. This work was funded by Diabetes UK (RD Lawrence Fellowship grant, BDA: 10/0003980) and by the Society for Endocrinology (Equipment grant, May 2016).

\section{Disclosure Statement}

The authors have nothing to disclose.

\section{References}

- 1 Wajchenberg BL: Beta-Cell Failure in Diabetes and Preservation by Clinical Treatment. Endocr Rev 2007;28:187-218.

- 2 Bosco D, Orci L, Meda P: Homologous but not heterologous contact increases the insulin secretion of individual pancreatic B-cells. Exp Cell Res 1989;184:72-80.

- 3 Brereton H, Carvell MJ, Persaud SJ, Jones PM: Islet alpha-cells do not influence insulin secretion from betacells through cell-cell contact. Endocrine 2007;31:61-65.

- 4 Hauge-Evans AC, Squires PE, Persaud SJ, Jones PM: Pancreatic beta-cell-to-betal-cell interactions are required for integrated responses to nutrient stimuli: enhanced $\mathrm{Ca} 2+$ and insulin secretory responses of MIN6 pseudoislets. Diabetes 1999;48:1402-1408.

- 5 Ishihara H, Maechler P, Gjinovci A, Herrera PL, Wollheim CB: Islet beta-cell secretion determines glucagon release from neighbouring alpha-cells. Nat Cell Biol 2003;5:330-335.

- 6 Leung YM, Ahmed I, Sheu L, Gao X, Hara M, Tsushima RG, Diamant NE, Gaisano HY: Insulin regulates islet alpha-cell function by reducing KATP channel sensitivity to adenosine 5 '-triphosphate inhibition. Endocrinology 2006;147:2155-2162.

- 7 Ravier MA, Rutter GA: Glucose or insulin, but not zinc ions, inhibit glucagon secretion from mouse pancreatic alpha-cells. Diabetes 2005;54:1789-1797.

8 Hauge-Evans AC, King AJ, Carmignac D, Richardson CC, Robinson IC, Low MJ, Christie MR, Persaud SJ, Jones PM: Somatostatin secreted by islet delta-cells fulfills multiple roles as a paracrine regulator of islet function. Diabetes 2009;58:403-411. 


\section{Cellular Physiology Cell Physiol Biochem 2019;52:486-502 \begin{tabular}{l|l|l}
\cline { 2 - 3 } DOI: 10.33594/000000035 & (c) 2019 The Author(s). Published by
\end{tabular} and Biochemistry Published online: 15 March $2019 \quad$ Cell Physiol Biochem Press GmbH\&Co. KG \\ Damsteegt et al.: Somatostatin and Pancreatic Beta Cell Survival}

9 Adriaenssens AE, Svendsen B, Lam BY, Yeo GS, Holst JJ, Reimann F, Gribble FM: Transcriptomic profiling of pancreatic alpha, beta and delta cell populations identifies delta cells as a principal target for ghrelin in mouse islets. Diabetologia 2016;59:2156-2165.

- 10 DiGruccio MR, Mawla AM, Donaldson CJ, Noguchi GM, Vaughan J, Cowing-Zitron C, van der Meulen T, Huising OM: Comprehensive alpha, beta and delta cell transcriptomes reveal that ghrelin selectively activates delta cells and promotes somatostatin release from pancreatic islets. Mol Metab 2016;5:449-458.

- 11 Lawlor N, George J, Bolisetty M, Kursawe R, Sun L, Sivakamasundari V, Kycia I, Robson P, Stitzel ML: Singlecell transcriptomes identify human islet cell signatures and reveal cell-type-specific expression changes in type 2 diabetes. Genome Res 2017;27:208-222.

- 12 Reichlin S: Somatostatin. N Engl J Med 1983;15;309:1495-1501.

- 13 Reichlin S: Somatostatin (second of two parts). N Engl J Med 1983;22;309:1556-1563.

- 14 Ferjoux G, Bousquet C, Cordelier P, Benali N, Lopez F, Rochaix P, Buscail L,Sunini C: Signal transduction of somatostatin receptors negatively controlling cell proliferation. J Physiol Paris 2000;94:205-210.

- 15 Pyronnet S, Bousquet C, Najib S, Azar R, Laklai H, Susini C: Antitumor effects of somatostatin. Mol Cell Endocrinol 2008;286:230-237.

16 Carrasco E, Hernandez C, Miralles A, Huguet P, Farres J, Simo R: Lower somatostatin expression is an early event in diabetic retinopathy and is associated with retinal neurodegeneration. Diabetes Care 2007;30:2902-2908.

- 17 Dal Monte M, Latina V, Cupisti E, Bagnoli P: Protective role of somatostatin receptor 2 against retinal degeneration in response to hypoxia. Naunyn Schmiedebergs Arch Pharmacol 2012;385:481-494.

- 18 Hernandez C, Garcia-Ramirez M, Corraliza L, Fernandez-Carneado J, Farrera-Sinfreu J, Ponsati B, Gonzalez-Rodriguez A, Valverde AM, Simo R: Topical administration of somatostatin prevents retinal neurodegeneration in experimental diabetes. Diabetes 2013;62:2569-2578.

- 19 Kokona D, Mastrodimou N, Pediaditakis I, Charalampopoulos I, Schmid HA, Thermos K: Pasireotide (SOM230) protects the retina in animal models of ischemia induced retinopathies. Exp Eye Res 2012;103:90-98.

20 Arroba AI, Mazzeo A, Cazzoni D, Beltramo E, Hernandez C, Porta M, Simo R, Valverde AM: Somatostatin protects photoreceptor cells against high glucose-induced apoptosis. Mol Vis 2016;22:1522-1531.

21 Jia C, Dai C, Bu X, Peng S, Xu F, Xu Y, Zhao Y: Co-administration of prostaglandin E1 with somatostatin attenuates acute liver damage after massive hepatectomy in rats via inhibition of inflammatory responses, apoptosis and endoplasmic reticulum stress. Int J Mol Med 2013;31:416-422.

22 Geci C, How J, Alturaihi H, Kumar U: Beta-amyloid increases somatostatin expression in cultured cortical neurons. J Neurochem 2007;101:664-673.

23 Basivireddy J, Somvanshi RK, Romero IA, Weksler BB, Couraud PO, Oger J, Kumar U: Somatostatin preserved blood brain barrier against cytokine induced alterations: possible role in multiple sclerosis. Biochem Pharmacol 2013;86:497-507.

24 Richardson CC, To K, Foot VL, Hauge-Evans AC, Carmignac D, Christie MR: Increased perinatal remodelling of the pancreas in somatostatin-deficient mice: potential role of transforming growth factor-beta signalling in regulating beta cell growth in early life. Horm Metab Res 2015;47:56-63.

- 25 Fernandez-Twinn DS, Ozanne SE: Mechanisms by which poor early growth programs type-2 diabetes, obesity and the metabolic syndrome. Physiol Behav 2006;88:234-243.

26 Amisten S: A rapid and efficient platelet purification protocol for platelet gene expression studies. Methods Mol Biol 2012;788:155-172.

27 Pfaffl MW: A new mathematical model for relative quantification in real-time RT-PCR. Nucleic Acids Res 2001;29:e45.

28 Cunha DA, Hekerman P, Ladriere L, Bazarra-Castro A, Ortis F, Wakeham MC, Moore F, Rasschaert J, Cardozo AK, Bellomo E, Overbergh L, Mathieu C, Lupi R, Hai T, Herchuelz A, Marchetti P, Rutter GA: Initiation and execution of lipotoxic ER stress in pancreatic beta-cells. J Cell Sci 2008;121:2308-2318.

29 Karaskov E, Scott C, Zhang L, Teodoro T, Ravazzola M, Volchuk A: Chronic palmitate but not oleate exposure induces endoplasmic reticulum stress, which may contribute to INS-1 pancreatic beta-cell apoptosis. Endocrinology 2006;147:3398-3407.

- 30 Akerfeldt MC, Howes J, Chan JY, Stevens VA, Boubenna N, McGuire HM, King C, Biden TJ,Laybutt DR: Cytokine-induced beta-cell death is independent of endoplasmic reticulum stress signaling. Diabetes 2008;57:3034-3044. 


\section{Cellular Physiology Cell Physiol Biochem 2019;52:486-502 \begin{tabular}{ll|l|l|l}
\hline DOI: 10.33594/000000035 2019 The Author(s). Published by \\
and Biochemistry
\end{tabular} and Biochemistry Published online: 15 March 2019 Cell Physiol Biochem Press GmbH\&Co. KG \\ Damsteegt et al.: Somatostatin and Pancreatic Beta Cell Survival}

31 Brozzi F, Nardelli TR, Lopes M, Millard I, Barthson J, Igoillo-Esteve M, Gireco FA, Villate O, Olivera M, Casimir M, Bugliani M, Engin F, Hotamisligil GS, Marchetti P, Eizirik DL: Cytokines induce endoplasmic reticulum stress in human, rat and mouse beta cells via different mechanisms. Diabetologia 2015;58:23072316.

- 32 Kharroubi I, Ladriere L, Cardozo AK, Dogusan Z, Cnop M, Eizirik DL: Free fatty acids and cytokines induce pancreatic beta-cell apoptosis by different mechanisms: role of nuclear factor-kappaB and endoplasmic reticulum stress. Endocrinology 2004;145:5087-5096.

- 33 Miyazaki J, Araki K, Yamato E, Ikegami H, Asano T, Shibasaki Y, Oka Y, Yamamura K: Establishment of a pancreatic beta cell line that retains glucose-inducible insulin secretion: special reference to expression of glucose transporter isoforms. Endocrinology 1990;127:126-132.

34 El-Assaad W, Buteau J, Peyot ML, Nolan C, Roduit R, Hardy S, Joly E, Dbaibo G, Rosenberg L, Prentki M: Saturated fatty acids synergize with elevated glucose to cause pancreatic beta-cell death. Endocrinology 2003;144:4154-4163.

35 Muller D, Jones PM, Persaud SJ: Autocrine anti-apoptotic and proliferative effects of insulin in pancreatic beta-cells. FEBS Lett 2006;580:6977-6980.

- 36 Efanova IB, Zaitsev SV, Zhivotovsky B, Kohler M, Efendic S, Orrenius S, Berggren PO: Glucose and tolbutamide induce apoptosis in pancreatic beta-cells. A process dependent on intracellular $\mathrm{Ca} 2+$ concentration. J Biol Chem 1998;273:33501-33507.

- 37 Bensellam M, Laybutt DR, Jonas JC: The molecular mechanisms of pancreatic beta-cell glucotoxicity: recent findings and future research directions. Mol Cell Endocrinol 2012;364:1-27.

- 38 Hauge-Evans AC, Reers C, Kerby A, Franklin Z, Amisten S, King AJ, Hassan Z, Vilches-Flores A, Tippu Z, Persaud SJ, Jones PM: Effect of hyperglycaemia on muscarinic M3 receptor expression and secretory sensitivity to cholinergic receptor activation in islets. Diabetes Obes Metab 2014;16:947-956.

- 39 Cnop M, Abdulkarim B, Bottu G, Cunha DA, Igoillo-Esteve M, Masini M, Turatsinze JV, Griebel T, Villate O, Santin I, Bugliani M, Ladriere L, Marselli L, McCarthy MI, Marchetti P, Eizirik DL: RNA sequencing identifies dysregulation of the human pancreatic islet transcriptome by the saturated fatty acid palmitate. Diabetes 2014;63:1978-1993.

40 Maury E, Brichard SM: Adipokine dysregulation, adipose tissue inflammation and metabolic syndrome. Mol Cell Endocrinol 2010;314:1-16.

41 Hasnain SZ, Borg DJ, Harcourt BE, Tong H, Sheng YH, Ng CP, Das I, Wang R, Chen AC, Loudovaris T, Kay TW, Thomas HE, Whitehead JP, Forbes JM, Prins JB, McGuckin MA: Glycemic control in diabetes is restored by therapeutic manipulation of cytokines that regulate beta cell stress. Nat Med 2014;20:1417-1426.

- 42 Cardozo AK, Ortis F, Storling J, Feng YM, Rasschaert J, Tonnesen M, Van Eylen F, Mandrup-Poulsen T, Herchuelz A, Eizirik DL: Cytokines downregulate the sarcoendoplasmic reticulum pump Ca2+ ATPase $2 \mathrm{~b}$ and deplete endoplasmic reticulum $\mathrm{Ca} 2+$, leading to induction of endoplasmic reticulum stress in pancreatic beta-cells. Diabetes 2005;54:452-461.

- 43 Pace CS, Tarvin JT: Somatostatin: mechanism of action in pancreatic islet beta-cells. Diabetes 1981;30:836842.

- 44 de Weille JR, Schmid-Antomarchi H, Fosset M, Lazdunski M: Regulation of ATP-sensitive K+ channels in insulinoma cells: activation by somatostatin and protein kinase $\mathrm{C}$ and the role of cAMP. Proc Natl Acad Sci U S A 1989;86:2971-2975.

45 Pinter E, Helyes Z, Szolcsanyi J: Inhibitory effect of somatostatin on inflammation and nociception. Pharmacol Ther 2006;112:440-456.

46 Luque RM, Cordoba-Chacon J, Pozo-Salas AI, Porteiro B, de Lecea L, Nogueiras R, Gahete MD, Castano JP: Obesity- and gender-dependent role of endogenous somatostatin and cortistatin in the regulation of endocrine and metabolic homeostasis in mice. Sci Rep 2016;6:37992.

- 47 Orci L, Baetens D, Rufener C, Amherdt M, Ravazzola M, Studer P, Malaisse-Lagae F, Unger RH: Hypertrophy and hyperplasia of somatostatin-containing D-cells in diabetes. Proc Natl Acad Sci U S A 1976;73:13381342.

- 48 Rahier J, Goebbels RM, Henquin JC: Cellular composition of the human diabetic pancreas. Diabetologia 1983;24:366-371.

- 49 Patel YC, Orci L, Bankier A, Cameron DP: Decreased pancreatic somatostatin (SRIF) concentration in spontaneously diabetic mice. Endocrinology 1976;99:1415-1418. 


\section{Cellular Physiology Cell Physiol Biochem 2019;52:486-502}

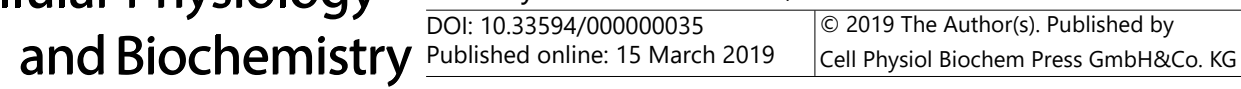

Damsteegt et al.: Somatostatin and Pancreatic Beta Cell Survival

- 50 Iki K, Pour PM: Distribution of pancreatic endocrine cells including IAPP-expressing cells in non-diabetic and type 2 diabetic cases. J Histochem Cytochem 2007;55:111-118.

- 51 Mosa R, Huang L, Li H, Grist M, LeRoith D, Chen C: Long-term treatment with the ghrelin receptor antagonist [d-Lys3]-GHRP-6 does not improve glucose homeostasis in nonobese diabetic MKR mice. Am J Physiol Regul Integr Comp Physiol 2018;314:R71-R83.

- 52 Strowski MZ, Blake AD: Function and expression of somatostatin receptors of the endocrine pancreas. Mol Cell Endocrinol 2008;286:169-179. 